Vogt, P. 1965: Zur Geologie von Südwest Hinks Land (Ostgrönland 71 30' N). Meddr Gronland 154, 5 , $24 \mathrm{pp}$.

Wenk, E. 1961: On the crystalline basement and the basal part of the pre-Cambrian Eleonore Bay Group in the southwestern part of Scoresby Sund. Meddr Grønland 168, 1, $54 \mathrm{pp}$.

Zweifel, H. 1959: Geologie und Petrographie von Nathorsts Land (NE-Grönland). Meddr Gronland 160. 3, 94 pp.

\title{
PRELIMINARY RESULTS OF MAPPING IN THE PALAEO- ZOIC AND MESOZOIC SEDIMENTS OF SCORESBY LAND AND JAMESON LAND
}

\author{
R. G. Bromley, J. Bruun-Petersen, and K. Perch-Nielsen
}

\section{Introduction}

In the 1969 summer season mapping was concentrated in those areas of southern Scoresby Land and northern Jameson Land which had not been visited in 1968 (see Birkelund \& Perch-Nielsen, 1969). Mapping was extended westward to the main fault of the post-Caledonian sedimentary basin against the Stauning Alper and to the south as far as $71^{\circ} 10^{\prime}$.

The field work was carried out by R. G. Bromley, L. and C. Malmros, K. PerchNielsen, J. Bruun-Petersen, C. Heinberg, and E. Hjelmar. The preliminary results of the mapping are given in this report together with a geological map at a scale of $1: 300000$, compiled from the existing maps (Aellen, in press; Bearth \& Wenk, 1959; Callomon, in press; Trümpy \& Grasmück; 1969) and our own observations. Special attention was given to trace fossils by. R. G. Bromley and the heavy mineral assemblages in the Mesozoic sediments by J. Bruun-Petersen.

\section{Palaeozoic}

Devonian

Outcrops of probably Upper Devonian age were found to underlie the Upper Permian basal conglomerate and reefy limestone in and on both sides of the river falling to the head of Nathorst Fjord. They consist of sandstones and shales with a few conglomerate beds and dip steeply westward.

(?) Carboniferous and Lower Permian

On the west side of the basin Palaeozoic sediments are down-faulted against the Caledonian crystalline of the Stauning Alper by a system of faults with a predomi- 
nant N-S strike. Kempter (1961) has mapped the Palaeozoic sediments west of Schuchert Flod and south of Ivar Baardsøns Gletscher. North of this area we were able to follow the main faults northwards where they disappear under the Schuchert Gletscher, south of $72^{\circ} \mathrm{N}$ lat. The sediments met with consist mainly of conglomerates and arkoses, some sandstones and dark shales. Conglomerates often contain pebbles of red granite; red feldspars occur in some of the conglomerates and arkoses, especially in the probably younger parts of this clastic series. A swarm of faults and poor exposures render measuring of the total thickness difficult but it is estimated to be more than $2000 \mathrm{~m}$. Direct correlation with the lithological units described by Kempter (1961) and by Aellen (in press) could not be established. The few plant fossils found could not be determined, so no new contribution as to the stratigraphical position of these sediments can be made. Kempter (1961) gave palynological evidence for a probable Carboniferous and Lower Permian age for sediments with comparable position and lithology.

Besides the outcrops in the valley of the Schuchert Flod and its slopes three small isolated patches of Palaeozoic clastic sediments were found to lie at an altitude of $1300 \mathrm{~m}$ on Caledonian crystalline rocks in the north-eastern corner of the area mapped. They are faulted down by a N-S striking fault and consist of breccious arkoses, conglomerates and arkoses up to about $150 \mathrm{~m}$ total thickness.

In the western part of Werner Bjerge, most of the sediments met with consist of (?) Carboniferous to Lower Permian clastic deposits. Hardened by the Tertiary intrusions they produce steep walls, often hardly accessible from the glaciers surrounding them. It was expected that direct correlation could be established with the lithological units described from the north (Witzig, 1954) and the south (Aellen, in press) but this was not possible even though this area connects the two already investigated areas. The sediments consist of indurated conglomerates, arkoses, sandstones, dark shales and a few thin calcareous bands. The thickness of the tectonically disturbed series is estimated to be more than $2000 \mathrm{~m}$. Only a few, as yet undetermined, plant remains have been found. In the conglomerates and arkoses two different associations of pebbles and feldspars could be observed: one contains many quartzites, light granites and feldspars, while the other contains red granites and red feldspars.

The contacts with the Tertiary intrusive bodies have not received special attention. Where observable they are rather sharp and the intrusions have no greater effect than baking the sediments in most of the area of the Werner Bjerge.

No Carboniferous deposits were found between the Devonian and Upper Permian sediments at the eastern border of the basin, although they are known to occur on Wegener Halvø.

Upper Permian

At the western border of the basin, marine Upper Permian deposits occur in small, slightly discordant patches on top of the clastic (?) Carboniferous - Lower Per- 
mian sediments and also north of faults striking WNW - ESE in the northernmost part of the area investigated. They begin with a basal conglomerate of probably marine origin, attaining $10 \mathrm{~m}$ in thickness. This contains many red granite pebbles and red arkose layers.There follow at least $40 \mathrm{~m}$ of gypsiferous layers with some thin calcareous and dolomitic intercalations. The overlying series of marly shales is baked by the Werner Bjerge intrusions and weathers to various colours. No fossils were found at Sirius Bjerg, where these deposits attain about $100 \mathrm{~m}$ in thickness.

The Upper Permian in Werner Bjerge does not develop the reefy facies that is seen in other parts of the basin, such as in the lower part of the valley of Schuchert Flod and Wegener Halvø. The reefy facies was met with at the head of Nathorst Fjord, where it is underlain by a thin basal conglomerate which, in turn, discordantly overlies Devonian sandstones. These Permian beds follow the strong postDevonian relief, leaving basins to be filled up by younger, clastic sediments of still higher Permian and lowermost Triassic age. In the upper part of the reefy limestone abundant brachiopods, crinoids and bryozoa, but no ammonites, were found. The uppermost part of the reefy limestones often contains thin veins with barytes, azurite and malachite.

\section{Mesozoic \\ 1. General}

The Mesozoic sediments which were studied in 1969 are the same lithostratigraphic units as those dealt with in 1968 (see Birkelund \& Perch-Nielsen, 1969). Furthermore the Triassic sediments of a part of the region have recently been described by Trümpy \& Grasmück (1969) and some new results concerning Middle Jurassic stratigraphy are to be presented by Birkelund, Håkansson \& Surlyk (in press). Therefore only new localities and observations are reported here.

\section{Wordie Creek Formation}

The marine Wordie Creek Formation could be studied and ammonites collected in the basins within the Upper Permian reefy limestones at the head of Nathorst Fjord, as well as in the area mapped by Aellen NE of Schuchert Flod. Within the western part of Werner Bjerge two badly preserved, baked ammonites were found, indicating a lowermost Triassic age for the youngest series in the north-western Werner Bjerge.

The Rødstaken Member was visited at its type locality east of Schuchert Flod. There, and south of Werner Bjerge, it is separated from the underlying silty shales and sandstones by a basal conglomerate which is lacking in the eastern part of the basin. 
Mt. Nordenskiöld Formation

Mapping in the western part of the basin gave no new information on subdivision of the members of the Mt. Nordenskiöld Formation. The formation is found in the valleys descending from Werner Bjerge towards the east and south.

In the eastern part of the basin, however, it was observed that the thickness of the Paradigma Member decreases rapidly from more than $450 \mathrm{~m}$ east of the head of Nathorst Fjord to only a few metres at the western head of Fleming Fjord, over the distance of about $10 \mathrm{~km}$.

Within the Solfaldsdal Member the Myalina Limestone horizon could be followed from the head of Fleming Fjord to the head of Nathorst Fjord. It rises from $400 \mathrm{~m}$ altitude in the west to $800 \mathrm{~m}$ half way between the two fjords and is then down-faulted to $600 \mathrm{~m}$ in the east where it shows silicification and contains jasper.

Table 1 .

\begin{tabular}{|c|c|c|c|}
\hline Sys & & \multicolumn{2}{|c|}{ Lithostratigraphical divisions } \\
\hline \multirow{5}{*}{ 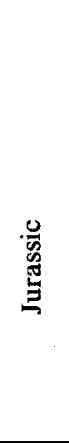 } & 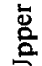 & \multicolumn{2}{|c|}{ Koch Fjeld Formation } \\
\hline & \multirow{3}{*}{ 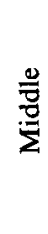 } & \multirow{3}{*}{ 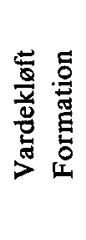 } & $\begin{array}{l}\text { Upper Vardekløft } \\
\text { Member }\end{array}$ \\
\hline & & & "The Yellow Series" \\
\hline & & & $\begin{array}{l}\text { Lower Vardekløft } \\
\text { Member }\end{array}$ \\
\hline & ב⿱ & \multicolumn{2}{|c|}{ Neill Klint Formation } \\
\hline \multirow{7}{*}{\multicolumn{2}{|c|}{$\begin{array}{l}\text { 号 } \\
\text { 愛 } \\
\text { f }\end{array}$}} & \multicolumn{2}{|c|}{$\begin{array}{l}\text { Kap Stewart Formation } \\
\text { (sensu Grasmück \& Trümpy) }\end{array}$} \\
\hline & & \multirow{3}{*}{ 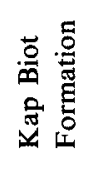 } & Ørsted Dal Member \\
\hline & & & Fleming Fjord Member \\
\hline & & & Kap Seaforth Member \\
\hline & & \multirow{2}{*}{ 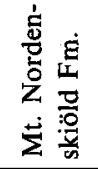 } & Solfaldsdal Member \\
\hline & & & Paradigma Member \\
\hline & & \multicolumn{2}{|c|}{$\begin{array}{l}\text { (Rødstaken Member) } \\
\text { Wordie Creek Formation }\end{array}$} \\
\hline
\end{tabular}




\section{Kap Biot Formation}

In the north-westernmost outcrops of the lowest member of the Kap Biot Formation, the Kap Seaforth Member, one very thin layer of algal stromatolites was found just south of Werner Bjerge. Such layers become thicker and more abundant towards the south and east. The Fleming Fjord Member almost disappears towards the north-east, giving place to a thickening of the overlying Ørsted Dal Member. The latter here also contains quartzite pebbles in the light sandstones and shows fewer signs of a marine origin than in the type area. No dolomitic layers such as those forming the top of the formation in Ørsted Dal could be found in the southern part of the Werner Bjerge, where the sediments of the Ørsted Dal Member are faulted down against (?) Carboniferous - Lower Permian deposits by a N-S striking fault.

\section{Kap Stewart Formation}

Dark shales and light sandstones belonging to the Kap Stewart Formation were found as the youngest sediments at the southern and eastern borders of the Werner Bjerge intrusive complex. Again, only few badly preserved plant fossils were found in this formation which, however, is known to contain well preserved plant fossils in southern Jameson Land.

\section{Neill Klint Formation}

The Neill Klint Formation was met with in the "graben" of south-eastern Scoresby Land and on some mountain tops in the same region, as well as at scattered localities in the southern and western parts of the area mapped in 1969. As in the previous year, only a few badly preserved ammonites were found in addition to the somewhat richer collections of other Toarcian fossils and an occurrence of abundant trace fossils.

No trace of the skeleton of a dinosaur discovered by H. Stauber in 1938 (pers. comm. 1969) within the Upper Neill Klint Formation was found at the locality near Skansen.

\section{Vardekløft Formation}

The extension of the Lower Vardekloft Formation and the overlying "Yellow Series" has been mapped in their northern occurrences, mainly in the "graben" of south-eastern Scoresby Land. In the south-western flat part of the area solifluction scree of the sandstones and shales of the "Yellow Series", together with moraine. cover most of the area. South-west of Olympen a few outcrops of the Upper Vardekløft Member were found.

Koch Fjeld Formation

On a short visit to Parnas ( $7 \mathrm{~km}$ east of Olympen) no fossils were found in the weathered sandstones of the Koch Fjeld Formation. 


\section{Heavy mineral assemblages}

The samples used for heavy mineral studies were collected during the field seasons 1968 and 1969 (fig. 2). In the laboratory the samples were treated in the usual way: crushing, treatment with hydrochloric acid (10 per cent), sieving (the fraction 250274 microns was used), and separation in heavy liquids $(D=2.9)$. One slide was made from each sample. So far about 100 samples have been studied, and the following minerals were found: tourmaline, zircon (and xenotime; the latter is sometimes mistaken for zircon), garnet (mostly almandine, very often etched), rutile, anatase and biotite. Opaque, decomposed biotites were not included in the counts. Amphibole and clinopyroxene were rare. Green hypersthene occurred in some samples. Brookite, sphene, staurolite, sillimanite, epidote, zoisite, monazite and picotite were found in very subordinate amounts. Barytes occurred in some samples, mostly around the Werner Bjerge intrusion.

About 200 grains were counted in each slide. In figs. 3 and 5 typical mineral associations are delineated as pie diagrams, which are cut up according to the percentage distribution of the mineral content. The centre of the diagram is placed as

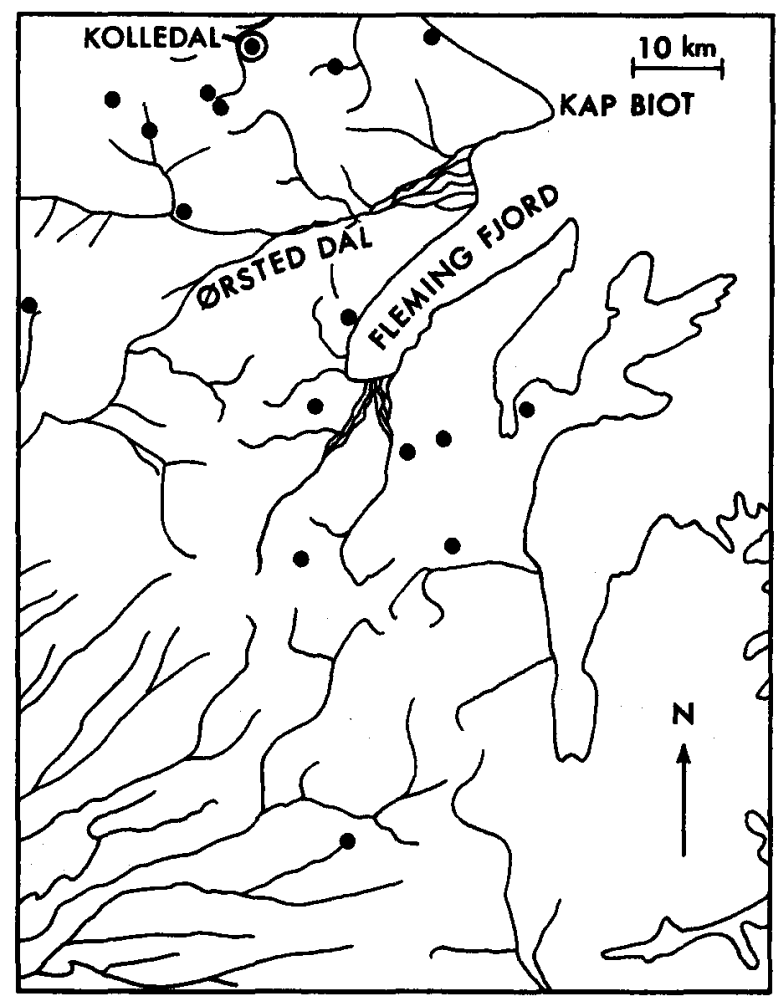

Fig. 2. Sample localities for heavy mineral analysis. 


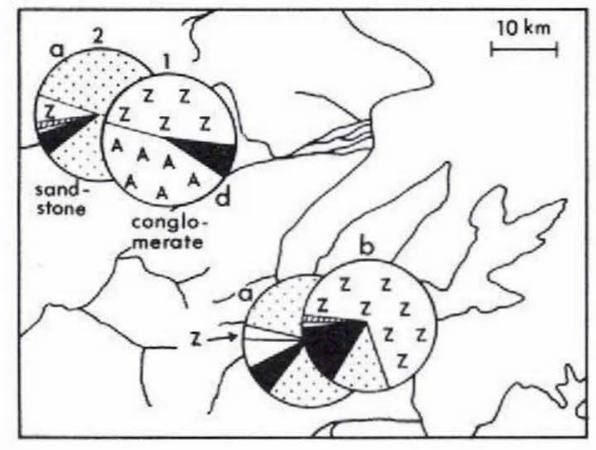

I. Wordie Creek Formation

excluding R $\phi$ dstaken Member.

Sample no. 2 is taken above no. 1 .

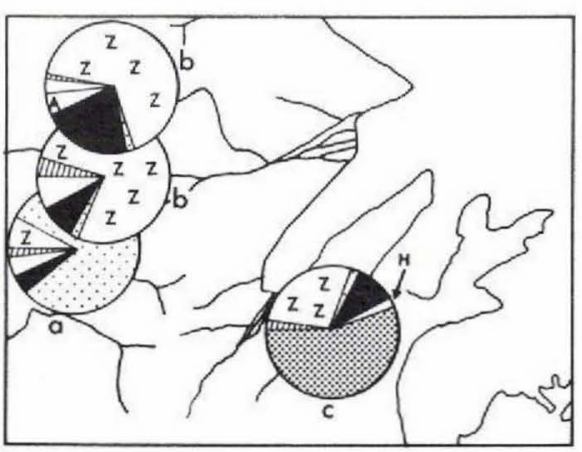

2. Rфdstaken Member.

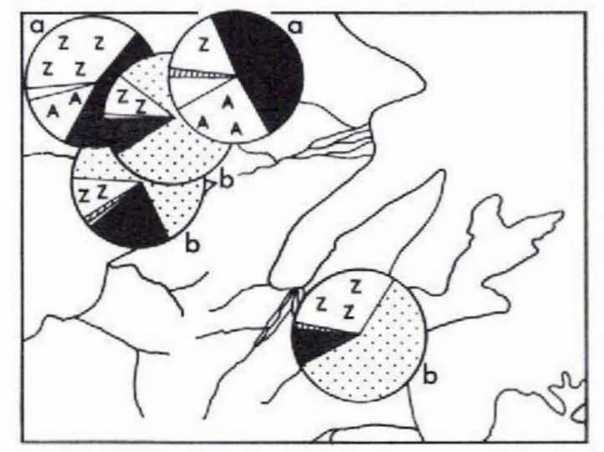

3. Paradigma Member.

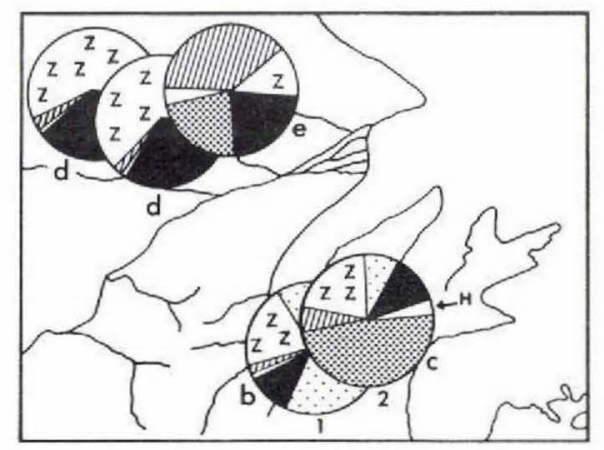

4. Solfaldsdal Member. Sample no. $I$ is taken above no. 2 .

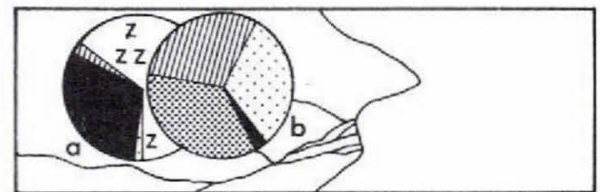

5. Kap Seaforth Member.

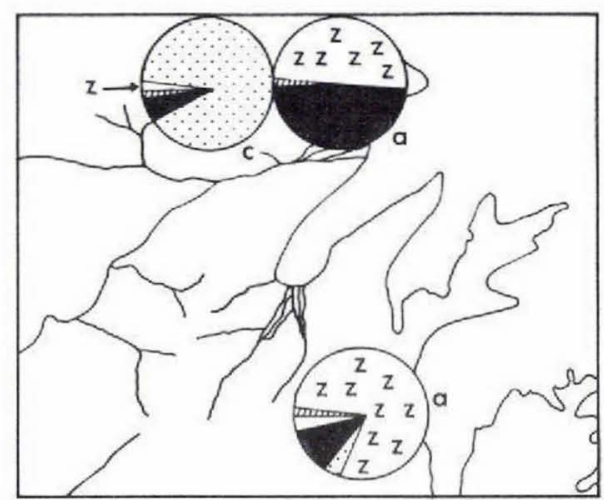

6. Fleming Fiord Member.

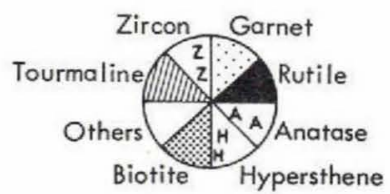

Legend to figs. 3 and 5 .

Fig. 3. The heavy mineral associations in the Wordie Creek Formation, the Mount Nordenskiöld Formation and the lower part of the Kap Biot Formation. 
close as possible to the sample locality. If more than one sample comes from the same locality, the diagrams are separated and the relative position of the samples is noted. The minerals are drawn in the same sequence as shown in the legend. In the text the most significant minerals are mentioned first, followed by the important accessory minerals, if any, in parentheses.

\section{Wordie Creek Formation}

The heavy mineral associations are shown in fig. 3, 1 and 3,2. Three associations are recognised: a) garnet- (zircon-rutile) association, b) a zircon-rutile association and c) a zircon-biotite-(hypersthene) association. The basal conglomerate (d) of the Wordie Creek Formation contains zircon, anatase and rutile.

Grasmück \& Trümpy (1969) suggested that the Rødstaken Member is the marine equivalent of the Paradigma Member of the Mount Nordenskiöld Formation. One of the heavy mineral associations is the same in both members (a in fig. 3,2 and $b$ in fig. 3,3. Note that $b$ and $c$ in fig. 3,2 correspond respectively to $d$ and $c$ in fig. 3,4.)

\section{Mount Nordenskiöld Formation}

In the area west of Nordenskiöld Bjerg it is clear that the Paradigma Member was deposited in large delta-cones, thickest at Nordenskiöld Bjerg and with rapidly decreasing thicknesses westward. These observations in particular support the theory that the arkoses in the eastern part of the area were deposited by large rivers coming from a land mass in the east.

The heavy mineral associations are shown on fig. 3,3 and 3,4. a) a zircon-rutile-anatase association was found in the Paradigma Member, b) a garnet-(zirconrutile) association in both members. In the Solfaldsdal Member the following associations were found: c) a zircon-biotite-(hypersthene) association, d) a zircon-rutile association and e) a tourmaline-rutile-biotite. In the Paradigma Member around Werner Bjerge barytes was found.

\section{Kap Biot Formation}

In the Kolledal section (figs. 2 and 4), a marked change in the heavy mineral assemblage was observed at the transition from the Mount Nordenskiöld Formation to the Kap Biot Formation. The tourmaline-rutile-biotite association (e in fig. 3,4) changes to a tourmaline-garnet-biotite association (b in fig. 3,5).

The Fleming Fjord and Ørsted Dal Members are mainly developed as siltstones and mudstones with the coarsest, most sandy beds to the north (figs. 3,6 and 5,1 ). The content of heavy minerals in some samples is very small. Glauconite was found in a sample from the Ørsted Dal Member in the valley northwest of Kap Biot.

In the formation as a whole the garnet association (c) was found only in the north-eastern part of the mapped area, and the zircon-rutile association (a) over 


\begin{tabular}{c|c|c|l}
\hline \multicolumn{2}{c|}{ MT. NORDENSKIÖLD FORMATION } & KAP BIOT FORMATION \\
\hline $\begin{array}{c}\text { PARADIGMA } \\
\text { MEMBER }\end{array}$ & $\begin{array}{c}\text { SOLFALDSDAL } \\
\text { MEMBER }\end{array}$ & $\begin{array}{c}\text { KAP SEAFORTH } \\
\text { MEMBER }\end{array}$ & $\begin{array}{l}\text { MLE- } \\
\text { FING } \\
\text { FERD } \\
\text { MER }\end{array}$ \\
\hline
\end{tabular}

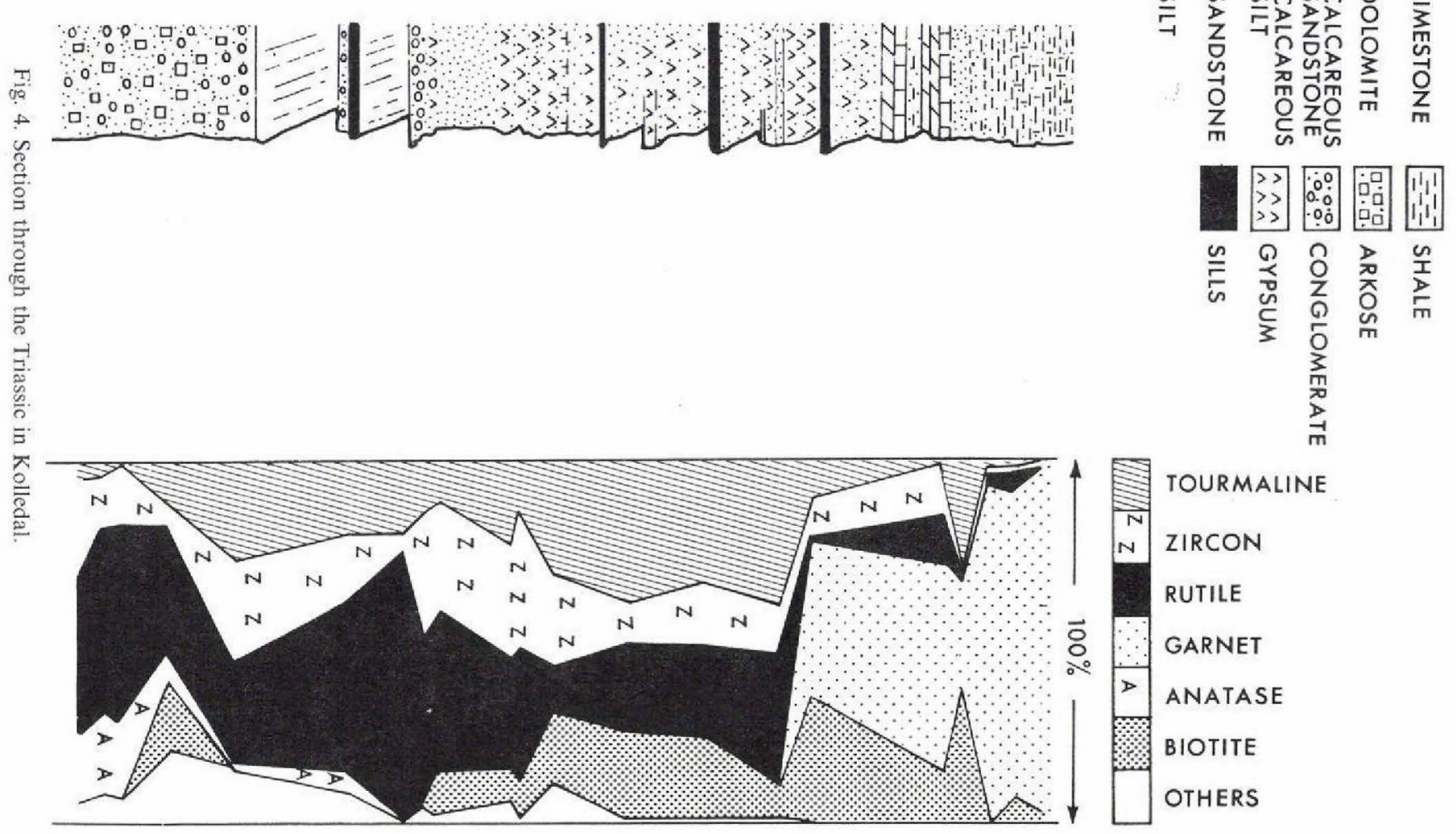


the whole area. A rutile-zircon-anatase association (d) was found in a sandy sample from the Ørsted Dal Member.

\section{Kap Stewart and Neill Klint Formations}

Changes in climatic conditions, or tectonic events, resulted in increased sedimentation of sandstones and black shales. Three heavy mineral associations were found (figs. 5,2 and 5,3): a) a tourmaline-zircon-rutile association, b) a tourmaline-garnet-rutile association and c) a zircon-biotite-(hypersthene) association. $\mathrm{Pa}$ laeogeographical conditions may have been approximately the same as in the older formations with the zircon-rutile-(tourmaline) association located in the northern and western part of the area, and the associations containing garnet in the eastern part.

\section{Vardekløft Formation}

The Lower Vardekløft Member (fig. 5,4) had a) zircon, garnet and hypersthene in a sample from the valley north-west of Kap Biot, and b) zircon, rutile and tourmaline in another sample; c) zircon, garnet and rutile were found together in the southern part of the area.

The "Yellow Series" (fig. 5,5) has its maximum thickness in the north of its outcrop and decreases in thickness southwards. The measured transport directions all indicate a sediment transport from the north-east and north-west towards south.

\section{Koch Fjeld Formation}

The few samples (fig. 5,6) were found to contain a heavy mineral association consisting of garnet, tourmaline, zircon, and rutile, in one case with biotite.

\section{Concluding remarks}

Three principal heavy mineral associations were found in the area: A) a garnet(zircon-rutile) association in the north-eastern and eastern part of the area, B) a zircon-rutile association, mostly in the northern part of the area, and C) an association containing zircon, biotite, hypersthene, garnet and rutile in varying amounts and located in the eastern part of the area visited. The anatase seems to be restricted to the coarse beds of different formations in the northern part of the area. Minor variations inside the associations are connected with differences in grain size of the sediments.

It is noteworthy that in most samples more than 90 per cent of the non-opaque heavy minerals comprise only 5 different types. Kleiber (1944), who previously dealt with the heavy minerals in the area, explained the monotony as a result either of poverty in the heavy mineral content of the parent rocks or of different stability of the minerals. 


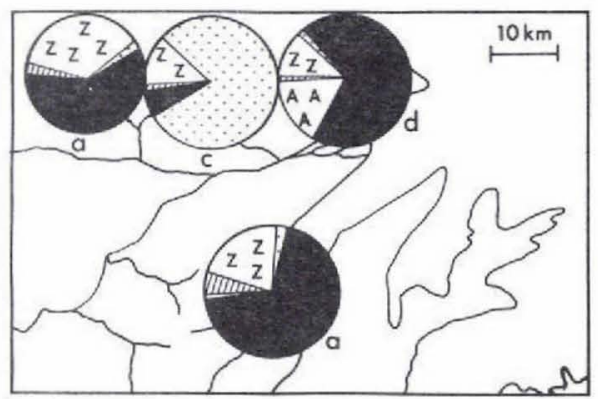

I. Фrsted Dal Member

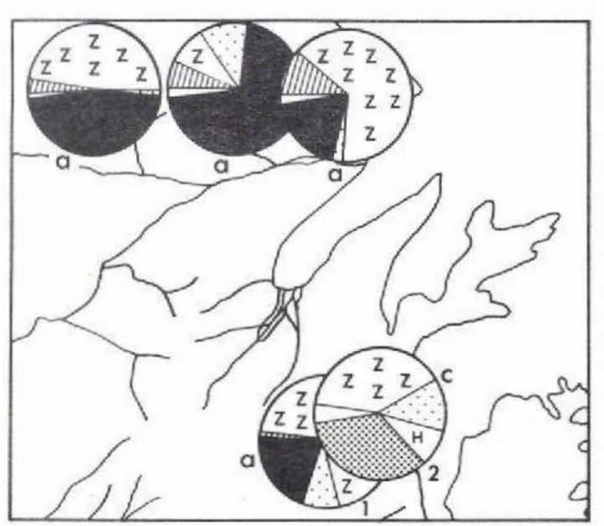

2. Kap Stewart Formation.

Sample no. 2 is taken above no. I.

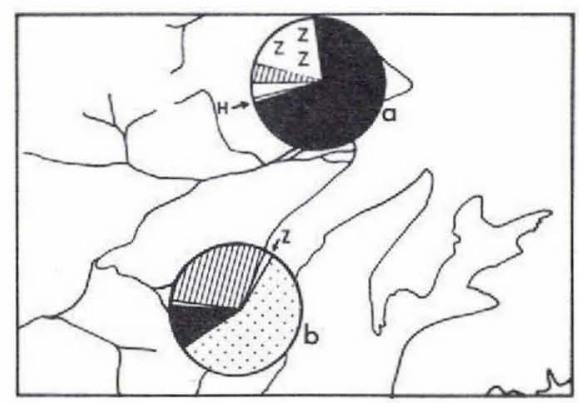

3. Neill Klint Formation.

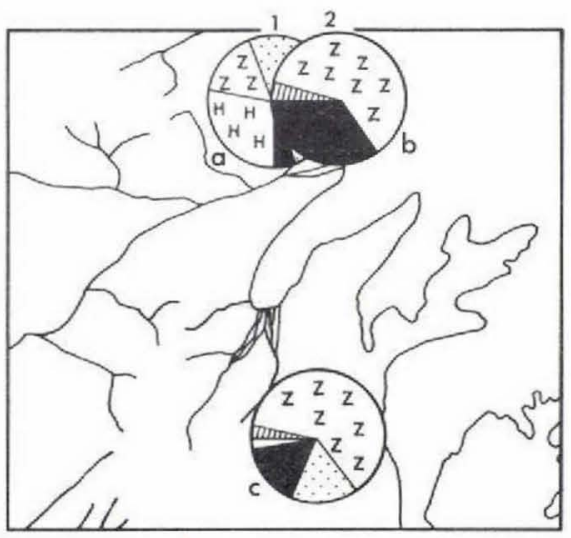

4. Lower Vardeklфft Member.

Sample no. 2 is taken above no. I.

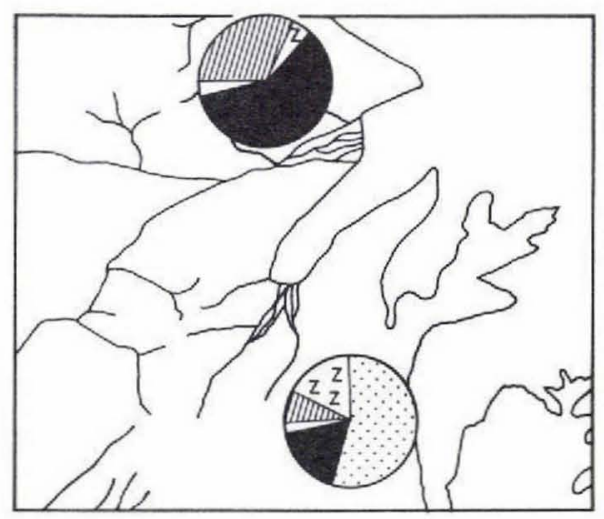

5. The "Yellow Series".

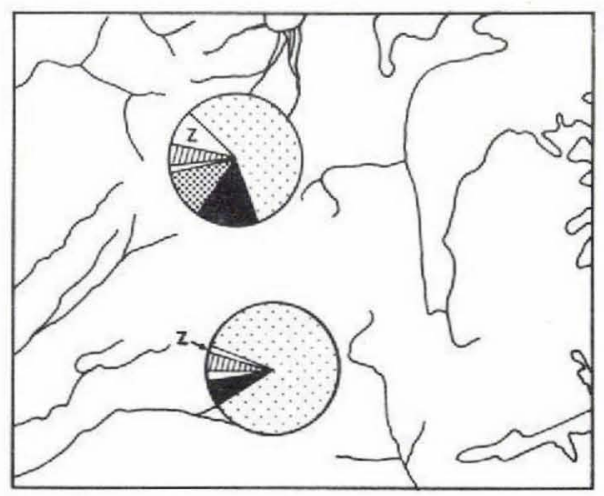

6. Koch Field Formation. 


\section{Trace fossils}

Trace fossils are well-preserved, varied and abundant throughout much of the Mesozoic succession of Jameson Land. Since this was already evident from the collections made during 1968, special attention was paid to ichnology in the 1969 season. The following notes record general results and emphasise further possibilities for work in the future in this field.

A day's traverse made from south of Skansen across Klitdal into Liverpool Land in an ESE direction produced promising results. The Fleming Fjord Member here contained well-preserved ichnofossils at a number of levels. At horizons of thin sandstones in these predominantly red-shaly beds, trace fossils were preserved in semi-relief and often showed very fine structure. Ichnocoenoses were often associated with ripple-marks, and comprised crawling and feeding trails (Planolites, "Hühnertrappen" and very fine, needle-like traces) and resting traces (Pelecypodichnus and small Rusophycus). Details of the ichnocoenoses varied from one horizon to another, and it appeared that a closer investigation would be rewarding.

In the lower part of the Lower Neill Klint Formation south-west of Skansen, locally developed, coarse, sand-bank sandstones were penetrated from their upper surfaces by vertical and oblique burrows (domichnia) among which were wellpreserved Diplocraterion yoyo (protrusive, retrusive and combined examples).

Thinner sandstones interbedded with shales higher in the same sequence yielded varied and well-preserved ichnocoenoses. These chiefly comprised horizontal feeding burrows with meniscus fill, Teichichnus, Gyrochorte, Curvolithus, meander trails and many ill-defined, small, resting and feeding traces.

On a brief visit to the west coast of the north end of Hurry Fjord, the Neill Klint Formation yielded well-preserved material differing in content from that from Skansen. A prominent, pink, arkosic sandstone outcropping at $370 \mathrm{~m}$, and full of vertical burrows, dominated the talus slope beneath. Above and below it, thinner, platy sandstones interbedded with shales were covered with many feeding trails and burrows. Some of these are well-preserved and well-defined requiring closer attention and further careful collecting. Internal, bilobate trails and meniscus-filled tunnels were common; as much material as could be carried was collected.

The top of the Upper Neill Klint Formation is marked by a highly fossiliferous sandstone in the Skansen region. The oysters and belemnites in this assemblage showed abundant borings of acrothoracican cirripedes and ctenostome bryozoans. This would appear to be the first report of hard substrate trace fossils from East Greenland where, although suitable substrates such as belemnites are common, borings are normally lacking. Some belemnites in the "Yellow Series" south-west of Olympen were also found to contain cirripede and bryozoan borings, but in this case the belemnites and their borings may have been reworked.

In the region south-west of Olympen the "Yellow Series", already noted for its 
trace fossils (Birkelund \& Perch-Nielsen, 1969, p. 30), was the subject of a special ichnological study. The first results of this work have been presented by Heinberg (in press). Briefly it may be said here that the series was found to comprise several types of sands and sandstones, each with a characteristic ichnocoenosis. Sandstones with a shallow-water aspect contained vertical burrows (single shafts and various forms of U-shaped burrows). Sandstones indicating quieter environments displayed feeding and crawling trails: Rhizocorallium, Curvolithus, bilobate trails, meniscus-filled tunnels, meanders and others.

It is remarkable that in the "Yellow Series" the presence of coarse mica in large quantities is chiefly responsible for the preservation of the trace fossils, particularly in the coarser sandstones. The flakes of mica, deposited horizontally, have been characteristically re-orientated by the passage of the animals through the sediment, revealing valuable information on the internal organisation of the trace fossils.

Thus the Mesozoic ichnocoenoses of Jameson Land all indicate shallow- to very shallow-water conditions of sedimentation. The vertical burrows in coarse sandstones represent a "Skolithos ichnofacies" while the remaining ichnocoenoses are of "Cruziana ichnofacies".

\section{Tertiary}

The Tertiary intrusive complex of Werner Bjerge has not received special attention, as it has been described by Bearth (1959). E. Hjelmar studied the sills and dykes around Werner Bjerge. The dykes vary in thickness from a few centimetres to 15 $\mathrm{m}$, the sills from one to over $100 \mathrm{~m}$ near Ørsted Dal. The direction of the dykes around Werner Bjerge was found to be variable with large numbers with trends of $10^{\circ}, 80^{\circ}$ and $125^{\circ}$. South of Olympen, however, the dykes show a general E-W trend. The regions with abundant thick sills generally lack major dykes.

\section{Structure}

The western border of the Jameson Land basin consists of mainly N-S striking faults. The (?) Carboniferous and Permian sediments east of the faults are downthrown against the crystalline rocks of the Stauning Alper to the west. Towards the east Triassic sediments are faulted down against the Palaeozoic deposits and only in the central part of the basin do Jurassic rocks occur. A "graben" structure was found to exist $20 \mathrm{~km}$ west of Kap Biot. The "graben" is deepest in the north and flattens towards the south where it almost disappears and is hardly noticeable when viewed from Ørsted Dal.

No faulting seems to have taken place in the southern part of the area mapped. 
Within Werner Bjerge NW-SE striking faults separate the (?) Carboniferous and Permian rocks from Upper Permian and lowermost Triassic strata. The main faults are possibly late Palaeozoic faults reactivated in Tertiary time.

\title{
References
}

Aellen, M. (in press). Geological map of the Gurreholms Bjerge and surrounding area east of Schuchert's Flod Northwest Jameson Land, East Greenland $71^{3 / 4}{ }^{\circ}$ N. Meddr Gronland 171, 3.

Bearth, P. 1959: On the alkali massif of the Werner Bjerge in East Greenland. Meddr Grenland 153, 4, 63 pp.

Birkelund, T. \& Perch-Nielsen, K. 1969 : Field observations in Upper Palaeozoic and Mesozoic sediments of Scoresby Land and Jameson Land. Rapp. Gronlands geol. Unders. 21, 21-35.

Birkelund, T., Håkansson, E. \& Surlyk, F. (in press) New finds of Bathonian, Callovian, and Oxfordian ammonites in northern Jameson Land, East Greenland. Meddr dansk geol. Foren. 20.

Callomon, J. H. (in press) Map 1:100 000. Meddr Gronland 168, 4.

Grasmück, K. \& Trümpy, R. 1969: Notes on Triassic stratigraphy and paleontology of north-eastern Jameson Land (East Greenland). Meddr Grønland 168, 21, 5-71.

Heinberg, C. (in press) Some Jurassic trace fossils from Jameson Land (East Greenland). Geol. J. (Special Vol.).

Kleiber, K. 1944: Beitrag zur Geologie und Sedimentpetrographie Ostgrönlands. Meddr Grønland 115, 4, 148 pp.

Kempter, E. 1961 : Die jungpaläozoischen Sedimente von Süd Scoresby Land. Meddr Grønland 164, 1, $123 \mathrm{pp}$.

Witzig, E. 1954: Stratigrapische und tektonische Beobachtungen in der Mesters Vig-Region (Scoresbyland, Nordostgrönland). Meddr Grønland 72, Afd. 2, 5, 26 pp.

\section{PRELIMINARY REPORT OF THE MAPPING OF THE BASALT AREA, SOUTH SCORESBY SUND}

\author{
W. Stuart Watt
}

Within the basalt area field activity in 1969 was concentrated mainly on the eastern part of Milne Land and extended over more scattered localities in the vicinity of Vikingebugt. On Gåseland a single traverse was made at Knækket.

\section{Milne Land}

Tertiary basalt covers the higher parts of eastern Milne Land (fig.6). The main part overlies gneisses directly, but to the east basalt lies on outliers of Jurassic sandstones which thin westwards. Basalts also cap the tops of Bays Fjelde. 